\title{
Electroacupuncture versus morphine for the postoperative control pain in dogs ${ }^{1}$
}

\author{
Eletroacupuntura versus morfina para o controle da dor pós-operatória em cães
}

\author{
Hugo Higa Gakiya', Danielle Alves Silva ${ }^{I I}$, Juliano Gomes ${ }^{I I}$, Helaine Stevanin ${ }^{I I I}$, Renata Navarro Cassu ${ }^{\text {IV }}$ \\ ${ }^{1}$ Research performed at Veterinary Hospital, Department of Veterinary Surgery and Anestesiology, Scholl of Veterinary Medicine, Oeste Paulista \\ University (UNOESTE), Presidente Prudente-SP, Brazil. \\ ${ }^{I}$ Fellow Master degree, Postgraduate Program in Animal Science, UNOESTE, Presidente Prudente-SP, Brazil. Acquisition of data, helped with technical \\ procedures, collection and processing of study informations, manuscript writing. \\ ${ }^{I I}$ Graduate student, Faculty of Veterinary Medicine, UNOESTE, Presidente Prudente-SP, Brazil. Helped with technical procedures, collection and \\ processing of study informations. \\ ${ }^{I I I}$ Full Professor, Department of Veterinary Surgery and Anestesiology, Scholl of Veterinary Medicine, UNOESTE, Presidente Prudente-SP, Brazil. \\ Responsible for surgical procedure. \\ Iv Full Professor, Department of Veterinary Surgery and Anestesiology, Scholl of Veterinary Medicine, UNOESTE, Presidente Prudente-SP, Brazil. \\ Mentor. Responsible for intelectual, scientific content and statistical analysis of the study. Critical revision.
}

\begin{abstract}
PROPOSE: To compare the postoperative analgesic effects of electroacupuncture, morphine or sham acupuncture in dogs undergoing mastectomy.

METHODS: Thirty client-owed dogs undergoing to mastectomy were randomly assigned to three groups of 10 animals each and received either morphine (T-M), the electroacupuncture (T-EA) or sham procedure (T-Sham). Pre-anesthetic medication was acepromazine (0.05 $\left.\mathrm{mg} \mathrm{kg}^{-1}, \mathrm{IM}\right)$. Anesthesia was induced with propofol (4 to $5 \mathrm{mg} \mathrm{kg}^{-1}, \mathrm{IV}$ ) and maintained with isoflurane. Postoperatively pain degree was assessed using a numerical rating scale. Dogs were scored at 1, 3, 6 and 12 hours post-extubation. If the pain score was $\geq 6$, supplemental morphine was administered. Serum cortisol concentration was measured before pre-anesthetic medication, at 45 minutes after the anesthetic induction, and at 1, 3 and 6 hours post-extubation.
\end{abstract}

RESULTS: The pain score did not differ among the treatments, but rescue analgesia was lower in the T-EA group ( 2 of 10 dogs), when compared with T-Sham ( 6 of $10 \mathrm{dogs}$ ) and T-M (6 of 10 dogs) groups. Serum cortisol concentration did not differ among the treatments. CONCLUSION: Electroacupuncture reduces the postoperative analgesic requirement and promotes satisfactory analgesia in dogs undergoing mastectomy.

Key words: Electroacupuncture. Analgesics, Opioid. Mastectomy. Dogs.

\section{RESUMO}

OBJETIVO: Comparar o efeito analgésico pós-operatório mediado pela aplicação de morfina, eletroacupuntura ou pontos falsos de acupuntura em cadelas submetidas à mastectomia.

MÉTODOS: Trinta cadelas encaminhadas para mastectomia foram aleatoriamente distribuídas em três grupos de dez animais cada, sendo tratadas com morfina (T-M), eletroacupuntura (T-EA) ou pontos falsos de acupuntura (T-sham). A medicação pré-anestésica (MPA) foi realizada com acepromazina $\left(0,05 \mathrm{mg} \mathrm{kg}^{-1}, \mathrm{IM}\right)$, seguindo-se a indução e manutenção anestésica com propofol (4 a 5 mg $\left.\mathrm{kg}^{-1}, \mathrm{IV}\right)$ e isofluorano, respectivamente. O grau de analgesia foi avaliado 1, 3, 6 e 12 horas após a extubação traqueal, empregandose a escala descritiva numérica. Animais, cujos escores foram $\geq 6$ receberam analgesia de resgate com morfina ( $\left.0,5 \mathrm{mg} \mathrm{kg}^{-1}, \mathrm{IM}\right)$. A concentração sérica de cortisol foi avaliada antes da MPA, aos 45 minutos após a indução anestésica e 1, 3 e 6 horas após a extubação traqueal. RESULTADOS: O escore de dor não variou entre os tratamentos, porém a analgesia resgate foi menos frequente no T-EA (2 de 10 animais), em relação ao T-sham (6 de 10 animais) e ao T-M (6 de 10 animais).

CONCLUSÃO: A eletroacupuntura reduz o requerimento analgésico pós-operatório e confere analgesia satisfatória em cadelas submetidas à mastectomia.

Descritores: Eletroacupuntura. Analgésicos Opioides. Mastectomia. Cães. 


\section{Introduction}

A mastectomy is an extensive and invasive procedure that results in inflammation, edema, and moderate to severe postoperative pain ${ }^{1}$, which are usually treated with non-steroidal anti-inflammatory (NSAID) drugs and opiates ${ }^{2}$. Furthermore, it should be noted that many patients who are referred for mastectomies are advanced in age, which can increase the adverse effects of conventional drugs used in analgesic therapy ${ }^{3}$.

In light of these factors, the use of complementary techniques that allow a reduction in the dosage of conventional analgesics is highly valuable because it can lower the incidence of possible adverse effects. Several trials have demonstrated that patients receiving acupuncture prior to surgery have a lower level of pain, reduced opioide requirement, a lower incidence of postoperative nausea and vomiting and lower sympatho-adrenal responses $^{4-7}$.

The objective of this study was to compare the postoperative analgesic effects mediated by the application of morphine, electroacupuncture, and false acupuncture points in female dogs undergoing mastectomies.

\section{Methods}

Thirty female, cross-breed dogs that weighed between 11 and $16 \mathrm{~kg}$ that were elected to undergo mastectomy procedures were evaluated. The exclusion criteria were renal or hepatic dysfunction according to laboratory tests (serum urea, creatinine, alanine aminotransferase, aspartate aminotransferase and alkaline phosphatase), severe cardiac changes diagnosed with chest X-rays, or the presence of pulmonary metastases identified by chest X-ray. The study was approved by the Oeste Paulista University Institutional Animal Research Ethical Committee and permission for participation of each dog was obtained from de owner.

After 12 hours-food and 3 hours-water fast, all of the animals underwent the same anesthetic protocol. Pre-anesthetic medication was intramuscular (IM) acepromazine $(0.05 \mathrm{mg} / \mathrm{kg})$. Thirty minutes later, the animals were randomly assigned to three treatment groups with 10 animals in each group. For the T-M group, morphine $(0.5 \mathrm{mg} / \mathrm{kg}$, IM) was simultaneously administered with acepromazine. For the T-EA group, electroacupuncture was applied at stomach 36 (ST36), spleen 6 (SP6) and gall bladder 34 (GB34), bilaterally. The T-Sham group received similar treatment to that described for the T-EA group; however, the needles were inserted into false acupuncture points, without electrical stimulation. The Tsu-san-li (ST36) acupoint is located 3 cun ( 1 cun = width of the last rib) distal to the lateral head of the fibula. The acupoint Yangling-chuan (GB 34) is located between the proximal insertion of tibia and fibula and the acupoint San-yin-chiao (SP 6) is located 3 cun proximal to the medial malleolus, at the caudal border of the tibia, close to the saphenous vein. The false points were selected in areas close to the real points, making sure that they were not points of other principal meridians. According to that, the false ST36, GB34 and SP6 points were located in the longus digital extensor and deep digital flexor muscles and caudal border of the Achilles tendon respectively ${ }^{8}$.

Electrostimulation (Sikuro) was applied 20 minutes before the anesthetic induction and was maintained throughout the surgical procedure. The $30 \times 0.25$ needles were introduced in the above points and the electrodes were attached to the body of the needles. An alternating square wave dense/disperse $0.2 \mathrm{~ms}$ (2$200 \mathrm{~Hz}$ ) electrical stimulus was used. The same electrical source of stimulation was used for the points GB34 and SP6 at one side, other source for the other side, and another source was used for bilateral stimulation of ST36 acupoints. The EA equipment was turned on and the intensity of the electrical stimulus started from zero and increased slowly until the animals showed signs of discomfort and presence of twitching.

After 20 minutes of the onset of the different treatments, the cephalic vein was catheterized for an anesthetic induction with propofol (4 to $5 \mathrm{mg} / \mathrm{kg}$, IV) Orotracheal intubation was performed and maintenance of anesthesia established with isoflurane in $100 \%$ oxygen in a small animal rebreathing circuit (Takaoka). Fluid therapy with lactated Ringer's solution (5 to $10 \mathrm{~mL} / \mathrm{kg} / \mathrm{h}$ ) was maintained during the entire surgical procedure. Five minutes before the surgical incision, meloxicam $(0.2 \mathrm{mg} / \mathrm{kg}$, IV) was administered.

The degree of postoperative analgesia was evaluated at $1,3,6$ and 12 hours post-extubation. The numerical pain scoring system (Table 1) was adapted from previously published systems ${ }^{9-11}$ which included relative increase in heart rate (measured by auscultation), respiratory rate and non-invasive arterial blood pressure (measured by Doppler method), salivary secretion, pupillary diameter changes, vocalization, degree of agitation, body position and response to palpation of the surgical site. All of the animals that obtained scores equal to or above 6 received rescue analgesia with morphine $(0.5 \mathrm{mg} / \mathrm{kg}, \mathrm{IM})$. The total number of morphine doses and their intervals were recorded. The pain score was tabulated independently by to persons that were blinded to the treatment group. 
TABLE 1 - Criteria used for scoring postoperative pain in dogs.

\begin{tabular}{|c|c|c|}
\hline Observation & Criteria & Score \\
\hline \multirow{4}{*}{ Heart rate } & $</=10 \%$ above preoperative value & 0 \\
\hline & $11 \%-30 \%$ above preoperative value & 1 \\
\hline & $31 \%-50 \%$ above preoperative value & 2 \\
\hline & $>50 \%$ above preoperative value & 3 \\
\hline \multirow{4}{*}{ Respiratory rate } & $</=10 \%$ above preoperative value & 0 \\
\hline & $11 \%-30 \%$ above preoperative value & 1 \\
\hline & $31 \%-50 \%$ above preoperative value & 2 \\
\hline & $>50 \%$ above preoperative value & 3 \\
\hline \multirow{4}{*}{ Arterial blood pressure } & $</=10 \%$ above preoperative value & 0 \\
\hline & $11 \%-30 \%$ above preoperative value & 1 \\
\hline & $31 \%-50 \%$ above preoperative value & 2 \\
\hline & $>50 \%$ above preoperative value & 3 \\
\hline \multirow[b]{2}{*}{ Salivation } & Normal & 0 \\
\hline & Above normal & 1 \\
\hline \multirow{3}{*}{ Mydriasis } & No & 0 \\
\hline & Yes & 1 \\
\hline & Quiet & 0 \\
\hline \multirow{2}{*}{ Vocalization } & Crying, responds to calming attempts & 1 \\
\hline & Crying no response & 2 \\
\hline \multirow{3}{*}{ Agitation } & Asleep or calm & 0 \\
\hline & Mild agitation & 1 \\
\hline & Moderate agitation & 2 \\
\hline \multirow[b]{3}{*}{ Body position } & Severe agitation & 0 \\
\hline & Sternal and relaxed & 1 \\
\hline & Protecting the incision site, including lateral and fetal position & 2 \\
\hline \multirow{4}{*}{$\begin{array}{l}\text { Response to palpation } \\
\text { of the incision site }\end{array}$} & No response & 0 \\
\hline & Mild response, looks at incision site & 1 \\
\hline & Turns head for the incision site, mild vocalization & 2 \\
\hline & Turns head with intention to bite, severe vocalization & 3 \\
\hline
\end{tabular}

Venous blood samples were collect from de jugular vein for the measurement of cortisol before pre-anesthetic medication (T-1), at 45 minutes after the anesthetic induction (T0), and at 1 (T1), 3 (T3) and 6 (T6) hours after the tracheal extubation. Serum samples were stored at $-70^{\circ} \mathrm{C}\left(-158^{\circ} \mathrm{F}\right)$ and analyzed within 12 months after collection. Measurement was performed using a solid phase radio-immunoassay (Coat-A-Count Cortisol - DPC).

The occurrence of adverse effects such as nausea, vomiting, tremors, excitement and drooling were also recorded.

Data were recorded as mean \pm SD. Statistical was performed using analysis of variance with the $\mathrm{F}$ test followed by
Tukey's test using Graphpad software, to investigate differences between treatments at each time, differences in time for each treatment, and interaction between treatment and time. A p-value less than 0.05 was considered significant.

\section{Results}

The three treatments were comparable in terms of demographic data (Table 2). There were no significant differences in pain scores among the groups at any time. Compared with findings at 3 and 6 hours and at 12 hours after extubation, pain 
scores were significantly $(\mathrm{P}<0.05)$ increased at 1 hour after extubation in T-sham and T-M treatment group, respectively. There was no change in pain scores in the T-EA group when the moments were compared (Figure 1).

TABLE 2 - Demographic and perioperative data (mean $\pm \mathrm{SD})$.

\begin{tabular}{lccc}
\hline & T-M & T-EA & T-Sham \\
\hline Age (years) & $10 \pm 3$ & $8 \pm 2$ & $8 \pm 2$ \\
Weight (Kg) & $11 \pm 7$ & $16 \pm 10$ & $12 \pm 10$ \\
Surgery duration (min) & $128 \pm 16$ & $120 \pm 40$ & $96 \pm 27$ \\
Extubation time (min) & $10 \pm 6$ & $5 \pm 2$ & $10 \pm 6$ \\
Recovery duration (min) & $114 \pm 53$ & $73 \pm 40$ & $53 \pm 37$ \\
Type of mastectomy (dog number) & & & 3 \\
Total mastectomy & 4 & 3 & 0 \\
Partial mastectomy (pre-umbilical) & 1 & 1 & 6 \\
Partial mastectomy (retro-umbilical) & 2 & 2 & 1 \\
Partial mastectomy (pre-retro-umbilical) & 3 & 4 & \\
\hline
\end{tabular}

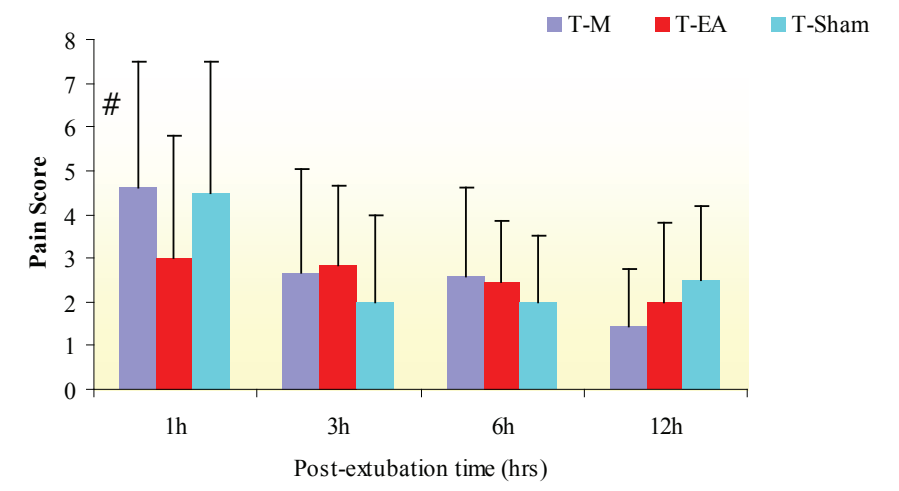

FIGURE 1 - Mean \pm SD pain scores in dogs treated with morphine (T-M), electroacupuncture (T-EA) or sham acupuncture (T-Sham) at each time period after tracheal extubation.

*Significant increase $(\mathrm{P}<0.05)$ when compared with 12 hours postextubation. "Significant increase $(\mathrm{P}<0.05)$ when compared with 3 and 6 hours after tracheal extubation.

Rescue analgesia was administered at 1 hour after extubation to 2 dogs that received EA treatment (T-EA); at 1, 3 and 6 hours after extubation to 6 dogs that received morphine treatment (T-M); and at 1 and 3 hours after extubation to 6 dogs that received sham treatment (T-Sham) (Figure 2).

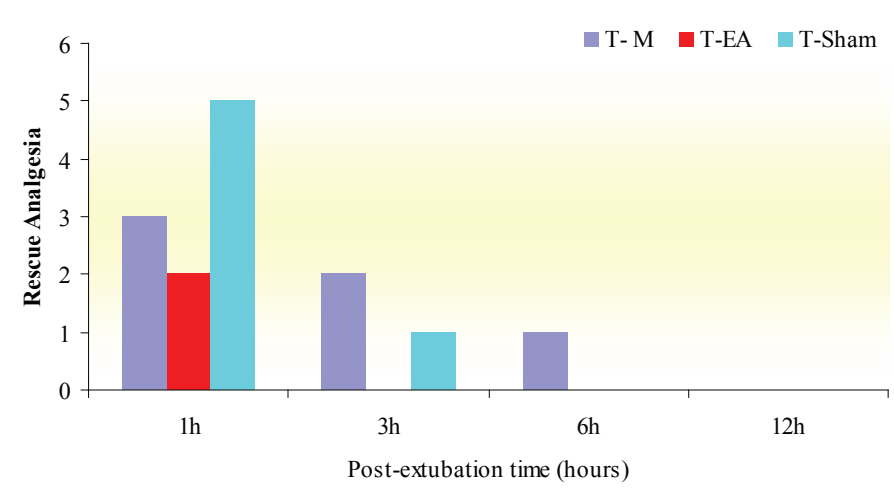

FIGURE 2 - Number of dogs that required rescue analgesia at various times after tracheal extubation.

Serum cortisol did not change among the treatments at any time. Compared with baseline data (T-1) and with findings at 6 hours (T6) after extubation, serum cortisol in all groups were significantly $(\mathrm{P}<0.05)$ increased at 1 hour after extubation $(\mathrm{T} 1)$ (Figure 3).

Undesirable side effects were not observed in any of the dogs.

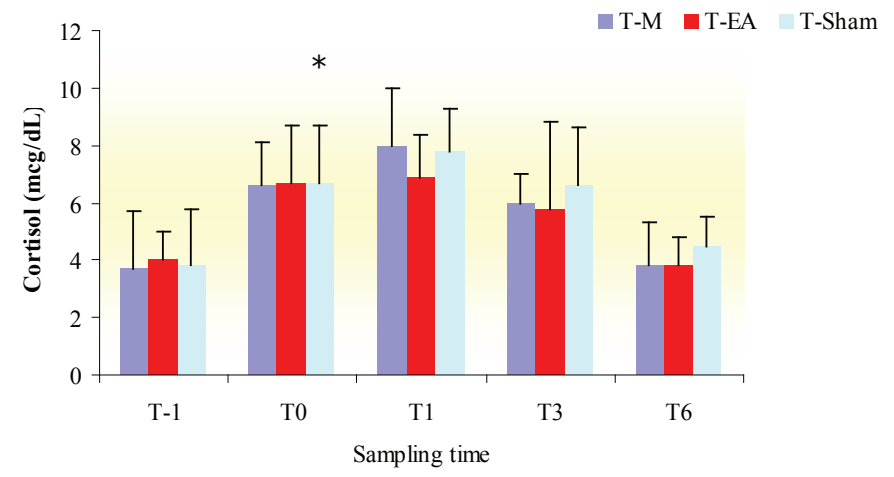

FIGURE 3 - Mean \pm SD serum cortisol concentration in dogs treated with morphine (T-M), electroacupuncture (T-EA) or sham acupuncture (T-Sham). T-1, before pre-anesthetic medication; T0, 45 minutes after anesthetic induction; T1, 1 hour; T3, 3 hours; T6, 6 hours after tracheal extubation.

*Significant increase $(\mathrm{P}<0.05)$ when compared with T-1 and T6.

\section{Discussion}

The results of human studies ${ }^{4-6}$ have indicated a decreased need for postoperative analgesics in patients treated with electoacupuncture before and/or during the surgical procedure. Similar results were observed in the present study. We observed less of a demand for supplementary post-operative analgesics in animals treated with electroacupuncture.

In the first hour of postoperative evaluation, the need for 
rescue analgesia was more evident in the animals treated with false acupuncture points compared to those treated with morphine or EA. Therefore, this treatment was less efficient than the others in inhibiting the nociceptive surgical response, demonstrating that it is necessary to stimulate specific points to obtain an analgesic effect, which has been described by other authors ${ }^{4,12}$. However, it is important to emphasize that the T-Sham animals, despite not having received the analgesic treatment with opiates, were treated with meloxicam in the preoperative period. This treatment, however, was not sufficient in inhibiting the immediate acute pain, which corroborates previous studies that have reported a greater analgesic efficiency of opiates in comparison to NSAID in the first hours following surgical trauma ${ }^{11,13}$. In the T-M group, only three dogs needed rescue analgesia in the first hour of evaluation, confirming the superior analgesic effect of this treatment due to the synergy resulting from the NSAID with opiates, where these findings are in concordance with previous results that have demonstrated that the analgesic effect is more pronounced with the use of both drugs than with either one by itself ${ }^{14}$. In contrast, only two of the animals treated with EA needed rescue analgesia during the postoperative evaluation, suggesting that this treatment obtained the best results in terms of the alleviation of postsurgical pain.

The exact mechanism of action of acupuncture in the control of pain is still not completely understood ${ }^{5}$. Some authors $^{8,15,16}$ agree with the classic "control gate" theory ${ }^{17}$, in which the stimulation of intradermal needles activates larger caliber nerve fibers (A $\beta$ fibers) in such a way that the perception of pain in the spinal cord is altered, and the transmission of pain sensation along the thin nerves is reduced, such as through $\mathrm{C}$ fibers $^{5}$. There is evidence that the EA stimulated the pain inhibition system in the spinal cord, the brainstem, and other areas of the central nervous system, such as the thalamus, the third ventricle of the midbrain, the diencephalon, the hypothalamus and the pituitary $^{12,18}$. Additionally, the release of endogenous opiates, such as endorphins, enkephalins, and dynorphins, also contributes to the analgesic effect mediated by acupuncture ${ }^{19}$.

The analgesic time induced by the EA is not completely clear. Human studies suggest that after a preoperative session of the EA, the analgesic effect lasts from 2-3 hours ${ }^{15,20,21}$. However, in the present study, the analgesic effect mediated by the EA had a longer duration, confirming previous results reported for both humans ${ }^{6}$ and $\operatorname{dog} \mathrm{s}^{22}$.

Many studies have led to recommendations of evaluation of the endocrine response as a complementary method to parametric and behavioral changes to measure pain in animals ${ }^{10,23,24}$. In this study, the baseline concentrations of cortisol in the dogs were similar to those observed in normal dogs $(0.96$ to $6.81 \mu \mathrm{g} / \mathrm{dl})$ by radioimmunoassay method ${ }^{25}$. Whereas the EA resulted in a better analgesic effect with a reduction in the need for morphine in the postoperative period, the cortisol did not vary among the types of treatment. This neuroendocrine response disagrees with previous results in people reporting that cortisol was reduced in patients treated with EA in comparison to those who were not ${ }^{5}$. Our present results demonstrated an increase in cortisol levels in all treatment groups when compared to the baseline values in the first hour of postsurgical evaluation, where these results are in agreement with previous studies ${ }^{9,10}$. In the sixth hour of postsurgical evaluation, serum cortisol returned to the baseline values, showing an attenuation of the stress response over time as a result of both the physiological neuroendocrine modulation ${ }^{23}$ and the rescue analgesia with morphine provided in the postoperative period. This is also in accordance with results previously reported in $\operatorname{dog} \mathrm{s}^{10}$.

The post-anesthetic recuperation was calm and gentle, without any occurrences of adverse effects, suggesting that the different techniques employed for analgesia did not interfere with the quality of post-anesthetic recuperation.

\section{Conclusions}

The stimulation of the acupoints ST36, GB34 and SP6 provides superior analgesia when compared to the preventive administration of morphine and the use of false acupuncture points. This provides a reduced need for analgesic opiates in the postoperative period in dogs undergoing mastectomy.

\section{References}

1. Mathews KA. Pain assessment and general approach to management. Vet Clin North Am Small Anim Pract. 2000;30(4):729-55.

2. Sarrau S, Jourdan J, Dupuis-Soyris F, Verwaerde P. Effects of postoperative ketamine infusion on pain control and feeding behaviour in bitches undergoing mastectomy. J Small Anim Pract. 2007;48(12):670-6.

3. Sackman JE. Pain and its management. Vet Clin North Am Small Anim Pract. 1997;27(6):1487-504.

4. Chen L, Tang J, White PF, Sloninsky A, Wender RH, Naruse R, Kariger R. The effect of location of transcutaneous eletrical nerve stimulation on postoperative opioid analgesic requirement: acupoint versus nonacupoint stimulation. Anesth Analg. 1998;87(5):1129-34.

5. Kotani N, Hashimoto H, Yuataka S, Sessler DI, Yoshioka H, Kitayama M, Yasuda T, Matsuki A. Preoperative intradermal acupuncture reduces postoperative pain, nausea and vomiting, analgesic requirement, and sympathoadrenal responses. Anesthesiology. 2001;95:349-56.

6. Sim $\mathrm{CK}, \mathrm{Xu}$ PC, Pua HL, Zhang G, Lee TL. Effects of 
electroacupuncture on intraoperative and postoperative analgesic requirement. Acupunct Med. 2002;20(2-3):56-65.

7. Still J. Anaesthetic and post-anaesthetic effects of placebo, buprenorphine and auricular electro-acupuncture in bitches ovariohysterectomized under halothane anaesthesia. J Altern Complement Med. 1997;16:26-33.

8. Cassu RN, Luna SPL, Clark RM, Kronka SN. Electroacupuncture analgesia in dogs: is there a difference between uni or bilateral stimulation? Vet Anaesth Analg. 2008;35:52-61.

9. Leibetseder EN, Mosing M, Jones RSA. Comparison of extradural and intravenous methadone on intraoperative isoflurane and postoperative analgesia requirements in dogs. Vet Anaesth Analg. 2006;33:128-36.

10. Mastrocinque S, Fantoni DT. A comparison of preoperative tramadol and morphine for the control of early postoperative pain in bitches submitted to ovariohisterectomy. Vet Anaesth Analg. 2003;30:2208.

11. Pibarot P, Dupuis J, Grisneaux E, Cuvelliez S, Planté J, Beauregard G, Bonneau NH, Bouffard J, Blais D. Comparison of ketoprofen, oxymorphone, and butorphanol in the treatment of postoperative pain in dogs. J Am Vet Med Assoc. 1997;211(4):438-44.

12. Chiu JH, Chung MS, Cheng HC, Yeh TC, Hsieh JC, Chang CY, Kuo WY, Cheng H, Ho LT. Different central manifestations in response to electroacupuncture at analgesic and nonanalgesic acupoints in rats: a manganese-enhanced functional magnetic resonance imaging study. Can J Vet Res. 2003;67(2):94-101.

13. Lascelles BD, Cripps P, Mirchandani S, Waterman A. Carprofen as an analgesic for postoperative pain in cats: dose titration and assessment of efficacy in comparison to pethidine hydrochloride. J Small Anim Pract. 1995;36(12):535-41.

14. Brondani JT, Loureiro Luna SP, Beier SL, Minto BW, Padovani CR. Analgesic efficacy of perioperative use of vedaprofen, tramadol or their combination in cats undergoing ovariohysterectomy. J Feline Med Surg. 2009;11(6):420-9.

15. Christensen PA, Rotne M, Vedelsdal R, Jensen RH, Jacobsen K, Husted C. Electroacupuncture in anaesthesia for hysterectomy. Br J Anaesth. 1993;71(6):835-8.

16. Wang B, Tang J, White PF, Naruse R, Sloninsky A, Kariger R, Gold $\mathrm{J}$, Wender RH. Effect of intensivity of transcutaneous acupoint eletrical stimulation on the postperative analgesic requirement. Anesth Analg. 1997;85(2):406-13.

17. Melzack R, Wall PD. Pain mechanisms. A new theory. Science. 1965;150(699):971-9.
18. Kho HG, Robertson EN. The mechanisms of acupuncture analgesia: review and update. Am J Acup. 1997;25:261-81.

19. Han JS. Acupuncture and endorphins. Neurosci Lett. 2004;361(13):258-61.

20. Christensen PA, Noreng M, Andersen PE, Nielsen JW. Electroacupuncture and postoperative pain. $\mathrm{Br} \mathrm{J}$ Anaesth. 1989;62(3):258-62.

21. Lao L, Bergman S, Langenberg P, Wong RH, Berman B. Efficacy of chinese acupuncture on postoperative oral surgery pain. Oral Surg Oral Med Oral Pathol Oral Radiol Endod. 1995;79(4):423-8.

22. Laim A, Jaggy A, Forterre F, Doherr MG, Aeschbacher G, Glardon O. Effects of adjunct electroacupuncture on severity of postoperative pain in dogs undergoing hemilaminectomy because of acute thoracolumbar intervertebral disk disease. J Am Vet Med Assoc. 2009;234(9):1141-6.

23. Fox SM, Mellor DJ, Firth EC, Hodge H, Lawoko CR. Changes in plasma cortisol concentrations before, during and after analgesia, anaesthesia plus ovariohysterectomy in bitches. Res Vet Sci. 1994;57(1):110-8.

24. Ko JC, Mandsager RE, Lange DN, Fox SM. Cardiorespiratory responses and plasma cortisol concentrations in dogs treated with medetomidine before undergoing ovariohysterectomy. J Am Vet Med Assoc. 2000;217(4):509-14.

25. Russell NJ, Foster S, Clark P, Robertson ID, Lewis D, Irwin PJ. Comparison of radioimmunoassay and chemiluminescent assay methods to estimate canine blood cortisol concentrations. Aust Vet J. 2007;85(12):487-94.

\section{Correspondence:}

Renata Navarro Cassu

Depto Cirurgia e Anestesiologia

Faculdade Medicina Veterinária e Ciência Animal - UNOESTE

19067-175 Presidente Prudente - SP Brasil

Tel: (55 18)3229-2077

navarro@unoeste.br

renavarro@uol.com.br

Received: January 18, 2011

Review: March 22, 2011

Accepted: April 25, 2011

Conflict of interest: none.

Financial source: FAPESP 